\title{
研究報告：
}

\section{中山間地域の診療所における 高齢者市中肺炎患者とフレイルの検討}

\author{
白石卓 也*
}

医療・介護関連肺炎 (nursing and healthcare-associated pneumonia : NHCAP) 診療 ガイドラインに，主治医は本人や家族の意向を尊重し，倫理面に配慮しながら高齢者肺炎 患者の治療方針を決めるべきだと示された。しかし，本人や家族と相談しても，高齢者肺 炎患者の多様な背景から治療方針の決定に迷うことがあった。そのため，何か高齢者特有 の指標があれば，高齢者肺炎患者における治療方針決定の一助となると考えた。近年，高 歯期に生理的予備能が低下することでストレスに対する脆弱性が立進し，生活機能障害， 要介護状態, 死亡などの転帰に陷りやすいフレイルが注目されている。そこで本研究で は，中山間地域に位置する当診療所で経験した高齿者市中肺炎患者とフレイルの関連を検 討した。対象患者は，2014年 4 月～2015年 1 月の間に診療所医師が診察し，外来や在宅で 肺炎を治療した，もしくは病院に搬送し肺炎を治療された当診療所に定期受診する75歳以 上の高齢者とした。治療前後の生活状況, NHCAP か否か, 初診時の重症度および治療前 のフレイルを調査した。調査期間中に肺炎の診断で治療された高齢者は 7 例（男性 3 例， 女性 4 例）で, 平均年齢は87.7歳であった。全例がNHCAP であり, 治療前フレイルと 判定された。NHCAP の中でもフレイルが進行するにつれて，生存や従来生活していた場 所への退院は難しかった。フレイルの評価は高齢者肺炎患者治療後の転帰の予測に有用 で，高齢者肺炎患者における治療方針決定の一助となる可能性が示唆された。

\section{(1)高齢者（2)フレイ （3)市中肺炎}

\section{緒言}

超高齢社会を迎えた本邦では，高齢者肺炎患 者を診察し治療する機会が増加している。在宅 高齢者の発熱の原因として最も多いのは肺炎で あり ${ }^{1)}$, 高齢者の肺炎は死亡率の高い疾患でも あるが2,3)，入院設備のない医療機関での高齢 者の外来および在宅治療ならびに病院へ搬送後 の転帰の報告は少ない。市中肺炎の診療では A -DROP システムで重症度を判定し, 治療方針

\footnotetext{
* = 370-1616 群馬県多野郡上野村大字乙父630-1 上野村へき地診療所

(受付：2015年 2 月17日）
}

を決めるが，高齢者肺炎患者の判定には不十分 であっだ)。予後不良な肺炎や耐性菌リスクの 高い肺炎は, 従来の市中肺炎や院内肺炎といっ た分類では捉えにくく，2011年に日本呼吸器学 会はこのような肺炎を医療・介護関連肺炎 (nursing and healthcare-associated pneumonia : NHCAP） と新しく定義し, NHCAP 診療ガイドラインが作成された。ガイドライン では, 主治医が本人や家族の意向を尊重し, 倫 理面に配慮しながら治療方針を決めるべきだと している。しかし，本人や家族と相談しても， 病院へ搬送するか, 看取りを含め外来や在宅で 治療するか, 判断に迷うことがあった。特にへ き地などで救急搬送に時間がかかる場合や 1 人 
で判断しなければならない場合は，自分の治療 方針は本当に正しかったか不安に思うことが あった。そのため, A-DROP システムに加え， 高齢者肺炎患者の治療後の転帰を予測でき，治 療方針決定の参考となるような指標が必要だと 考えた。高齢期に生理的予備能が低下すること でストレスに対する脆弱性が立進し，生活機能 障害, 要介護状態, 死亡などの転帰に陥りやす い状態として，2014年に日本老年医学会はフレ イルを提唱した。一般的に高齢者の虚弱状態を 加齢に伴って不可逆的に老い衰えた状態と理解 されることも多いが，フレイルの概念は，しか るべき介入により再び健常な状態に戻るという 可逆性が含まれ，超高齢社会の本邦にとって高 齢者の介護予防における観点でその重要性が注 目されている。そこで本研究では，中山間地域 に位置する当診療所で経験した高齢者市中肺炎 患者とフレイルの関連を検討した。

\section{対象および方法}

対象とした当診療所は，人口約 1,350 人，高 齢化率約 $45 \%$ の上野村にある唯一の医療施設で あり，最寄りの医療機関まで30分以上かかるこ とからへき地診療所と定義されている。1 日外 来患者数は30〜 40名程度であり，1 人の医師が 診療している。当診療所では，75歳以上の定期 受診患者を 300 名以上抱え，診療時間外の緊急 往診は随時受け付けている。

対象患者は，2014年 4 月～2015年 1 月の間に 診療所医師が診察し，外来や在宅で肺炎を治療 した，もしくは病院に搬送し肺炎を治療された 当診療所に定期受診する75歳以上の高齢者とし た。その経過は当診療所のカルテおよび入院先 病院の診療情報提供書を参考にした。また，治 療前後の生活状況，NHCAP の定義に該当する か否かおよび初診時における重症度を日本呼吸 器学会の成人市中肺炎診療ガイドラインにある 重症度分類システム（A-DROP システム）を 使い，年齢（Age），脱水（Dehydration），動 脈血酸素飽和度（Respiration），意識障害

(Orientation)，血圧 (Pressure) の 5 項目か ら判定した。さらに，治療前のフレイルを調査
した。フレイルの定義や診断基準について多く の議論が行なわれているが，コンセンサスは得 られていない。その評価法のひとつである frailty index は生命予後を含め, 将来の健康障 害の予測因子として有用であると多く報告され ている ${ }^{5 \sim 7)}$ 。しかし，評価項目が多いため臨床 現場で使いにくく，frailty index と遜色なくフ レイルを評価できる方法として clinical frailty scale（以下；CFS）が開発された8)。今回，臨 床で簡便に使用できる CFS を使いフレイルを 評価した。CFSは9段階で判定し，手段的日 常生活動作が困難となった段階である 5 以上を フレイルと定義している8)。CFS の判定は，定 期受診時の診察と本人や家族, 施設職員から聴 取した日常生活動作をもとにした。

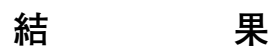

対象期間とした 8 か月間に肺炎の診断で治療 された75歳以上の高齢者は男性 2 名および女性 4 名の合計 6 名で，そのうち男性 1 名は 2 回肺 炎を起こし，対象症例は合計 7 例であった。平 均年齢は87.7歳（83〜94歳）であった。肺炎発 症前に自宅で過ごしていた患者は 3 例で，グ ループホームは 4 例であった。いずれの症例も 複数の基礎疾患をもっていた。全例が performance status 3 以上であり，NHCAP の定義に 該当した（表 1 )。

A-DROP システムによる初診時の重症度判 定では，重症は 2 例で，中等症は 5 例であった

（表 2 ）。意識障害や血圧低下を認めた重症や 超重症の高齢者肺炎患者は，調査期間中にいな かった。

A-DROP システムで初診時に重症と判定し た 2 例に入院治療をすすめたが，1 例は本人と 家族の希望があり在宅治療した。病院へ搬送し た 1 例は，集中治療室で治療され，ADL は低 下したが今までいたグループホームへ退院する ことができた。在宅治療を希望した 1 例は，治 療開始後 9 日目に死亡した。鎮痛薬を使用する ことで苦痛の訴えなく自宅で看取ることができ た。初診時に中等症と判定した 5 例のうち病院 へ搬送し入院治療された患者は 2 例で， 1 例が 
表 1 ．患者背景

\begin{tabular}{|c|c|c|c|c|c|}
\hline 症例 & 年齢 & 性別 & $\begin{array}{l}\text { Performance } \\
\text { status }\end{array}$ & 生活場所 & 基 礎 疾 患 \\
\hline 1 & 94 & 女性 & 4 & 自宅 & 脳梗塞, 胃悪性リンパ腫, 総胆管結石 \\
\hline 2 & 89 & 女性 & 3 & グループホーム & 認知症, 高血圧症, 骨粗鬆症, 逆流性食道炎 \\
\hline 3 & 86 & 男性 & 3 & グループホーム & $\begin{array}{l}\text { 高血圧症, 左慢性硬膜下血腫, 前立腺肥大症, B 型 } \\
\text { 慢性肝炎 }\end{array}$ \\
\hline 4 & 83 & 男性 & 3 & グループホーム & 認知症, 高血圧症, うつ病, 腹部大動脈瘤術後 \\
\hline 5 & 94 & 女性 & 3 & 自宅 & $\begin{array}{l}\text { 高血圧症, 脳出血, 骨粗髢症, 胸椎圧迫骨折, 胃癌 } \\
\text { 術後, 大腸癌術後 }\end{array}$ \\
\hline 6 & 85 & 女性 & 3 & 自宅 & $\begin{array}{l}\text { 脳梗塞, 高血圧症, 脂質異常症, 骨粗鬆症, 両側変 } \\
\text { 形性股関節症 }\end{array}$ \\
\hline
\end{tabular}

表 2．A-DROP システムによる初診時の重症度評価

\begin{tabular}{|c|c|c|c|c|c|c|c|}
\hline 症例 & Age & Dehydration & Respiration & Orientation & Pressure & Score & 重症度判定 \\
\hline 1 & + & - & - & - & - & 1 & 中等症 \\
\hline 2 & + & - & - & - & - & 1 & 中等症 \\
\hline 3 & + & + & - & - & - & 2 & 中等症 \\
\hline $4-1$ & + & + & + & - & - & 3 & 重症 \\
\hline $4-2$ & + & - & - & - & - & 1 & 中等症 \\
\hline 5 & + & + & + & - & - & 3 & 重症 \\
\hline 6 & + & - & - & - & - & 1 & 中等症 \\
\hline
\end{tabular}

表 3. Clinical frailty scale (CFS), 重症度および治療後経過の関係

\begin{tabular}{cccll}
\hline 症例 & 治療前 CFS & 初診時の重症度 & 治療場所 & \multicolumn{1}{c}{ 治療後経過 } \\
\hline 1 & 8 & 中等症 & 在宅 & 死亡 \\
2 & 7 & 中等症 & 病院 & 死亡 \\
3 & 7 & 中等症 & 病院 & 療養型病院 \\
$4-1$ & 5 & 重症 & 病院 & グループホーム \\
$4-2$ & 6 & 中等症 & 外来 & グループホーム \\
5 & 7 & 重症 & 在宅 & 死亡 \\
6 & 6 & 中等症 & 外来 & 自宅 \\
\hline
\end{tabular}

治癒し， 1 例が死亡した。治癒した 1 例は，療 養型病院に転院した。また，入院治療の希望な く在宅や外来で治療した患者は 3 例で， 2 例が 治癒し，1例が死亡した。死亡した 1 例は, 徐々に呼吸状態の悪化を認めたが，呼吸苦など 苦痛の訴えなく自宅で看取ることができた（表 3 )。
全例が治療前 CFS 5 以上であり，フレイル と判定された。治療前 CFS 5 および 6 であっ た症例は 3 例で，肺炎治療後も肺炎発症前と同 じ自宅もしくはグループホームで生活してい る。治療前 CFS 7 抢よび 8 であった症例は 4 例で，そのうち 3 例が死亡し， 1 例はもともと グループホームにいたが，病院で治療された 
後, 療養型病院へ転院した（表 3 ）。

\section{考察}

2011年の厚生労働省・人口動態統計で，肺炎 は日本人の死因の第 3 位となった。本邦の肺炎 死亡の $98 \%$ \%5歳以上の高齢者であるため，世 界に類をみない高齢化の進行が一因である。現 在，肺炎患者の約 $70 \%$ は院治療されてい る ${ }^{9)}$ 。70歳以上の肺炎入院患者のうち $80.1 \%$ に 誤嚥が認められ ${ }^{10)}$ ，在宅で寝たきりの高齢者に 起こった肺炎の $92 \%$ に誤嚥が関与している ${ }^{11} 。$ 高齢者の誤嚥性肺炎は，予後不良かつ在院日数 延長の要因であり医療機関や医療経済の負担は 大きい ${ }^{12)}$ 。平成23年患者調査によれば肺炎患者 の入院患者数や外来患者数は年々増加してい る。2025年には団塊の世代の人たちが75歳以上 となり, 全人口の 4 人に 1 人が後期高齢者とい う超高齢社会が到来する。そのため，今後高齢 者肺炎患者数は増加し, 医療機関や医療経済の 負担はさらに大きくなると考えられる。

超高齢社会を迎えた本邦で，高齢者肺炎患者 を在宅で治療すれば，医療機関や医療経済の負 担が軽減され，患者の希望に添った医療を行な える可能性がある。本邦では 8 割以上の患者は 病院で死亡しているが，国が行なったアンケー トでは 6 割以上の方は在宅での療養を望んでい た ${ }^{13)}$ 。しかし，看取りを含めた在宅医療は国が 期待するほど増えていない。今回，自宅で看 取った症例は，あらかじめ本人や家族の希望を 聞き，最後は家で迎えたいと相談してきた患者 だった。高齢者の肺炎の経過や予後を患者と家 族へ説明し，共通理解のうえで在宅治療を決め た。しかし，高齢者肺炎患者を在宅治療した場 合と病院へ搬送した場合との転埽の報告はほと んどなかったため, 在宅治療の判断は正しかっ たか，在宅治療後の経過を十分に説明できてい たか不安に感じた。医療者が患者と家族へ自信 を持って治療方針を提示し，高齢者肺炎患者を 外来や在宅で看取りを含め治療するためには， その高齢患者の治療後の転帰を予測できる指標 が必要だと考えた。

高齢者市中肺炎患者の治療方針を決める場
合, A-DROP システムの重症度判定だけでは 不十分である4)。病院へ搬送するか，看取りを 含め外来や在宅で治療するかについては，高齢 者肺炎患者の様々な要素を考慮する必要があ る。高齢者肺炎患者に対し若年者と同様に積極 的な治療を行なうことは延命や多少の症状緩和 につながるが，患者の QOL を著しく低下させ てしまうことも多い(14)。そのため, NHCAP 診 療ガイドラインに示されているように， NHCAP の高齢患者の治療方針は，本人と家族 と日常をよく知る医師の意見をもとに，ADROP システムでは評価できない部分を総合 的に判断して決められるべきである。しかし， 高齢者肺炎患者は多様な背景をもち，治療方針 を決める指標や報告がほとんどないため，医師 それぞれの価值観や倫理観により治療方針は異 なってしまう。そのため, 自分の治療方針は本 当に正しかったか，本人や家族の望んだ結果と なったか不安に思い，診療した医師はストレス を感じることがある。医師の心の負担を軽くす るためにも，A-DROP システムに加え，高齢 者肺炎患者の治療後の転帰を予測でき, 治療方 針決定の参考となるような指標が必要だと考え た。

市中肺炎患者の重症度評価において, ADROP システムで評価されない項目は, $\mathrm{ADL}$ ，栄養状態，認知機能抒よび基礎疾患な どである。それらは高齢者の肺炎発症の危険因 子であり，死亡率とも関連している ${ }^{15)}$ 。フレイ ルは, ADL, 栄養状態, 認知機能など A-DROP システムでは評価されない項目を含んだ概念で ある。報告によれば，フレイルは年齢とは独立 して健康障害や死亡の予測因子となり得 る $^{16,17)}$ 。また，フレイル高齢者ではガイドライ ンに従い血圧や $\mathrm{HbA} 1 \mathrm{c}$ を管理することでか えって予後を悪化させたという報告もあ る ${ }^{18,19)}$ 。以上の報告から，高齢者肺炎患者とフ レイルとは，何らかの関連があるのではないか と考えた。

今回の結果から，A-DROP システムによる 重症度判定と治療後の転帰の関連は示唆されな かった。対象となった全ての症例が NHCAP 
であったため, NHCAP の患者の予後を重症度 から予測することができないという NHCAP 診療ガイドラインに示されている内容と一致し ていた。一方，フレイルと治療後の転帰の関連 が示唆された。死亡した症例あるいは従来生活 していた場所へ退院できなかった症例は，治療 後に生存し従来と同じ場所で生活している症例 よりも治療前 CFS は高く, 治療前 CFS 7 以上 であった。つまり，同じNHCAP の高齢患者 の中でも, フレイルの進行している症例は治療 後の転帰が悪かった。フレイルを評価すること により，NHCAP の高齢患者治療後の転帰を予 測でき，高齢者肺炎患者における治療方針決定 の一助となる可能性が示唆された。しかし, 本 研究の症例数は 7 例と少なく特定の地域だけを 対象としているため, 対象者数や地域を拡大し た研究によって検討することが今後の課題であ る。

\section{結語}

フレイルの評価は高齢者肺炎患者治療後の転 州の予測に有用で，高齢者肺炎患者における治 療方針決定の一助となる可能性が示唆された。 高齢者肺炎患者の治療後の転帰を予測し，患者 と家族へ適切な治療方針を提示することで，医 師の心の負担は軽減し，患者や家族の希望に 添った医療を提供できると考えられた。

\section{著者のCOI 開示}

本論文発表内容に関連して特に申告なし。

$$
\text { 文献 }
$$

1 ) Yokobayashi K, Matsushima M, Watanabe T, et al. Prospective cohort study of fever incidence and risk in elderly persons living at home. BMJ Open $2014 ; 4(7)$ : e004998.

2 ) Arias E, Anderson RN, Kung HC, et al. Deaths : final data for 2001. Natl Vital Stat Rep 2003 ; $52(3): 1-115$.

3 ) DeFrances CJ, Hall MJ. 2002 National Hospital Discharge Survey. Adv Data $2004 ;(342): 1-$ 29.

4 ）樋口多恵子, 太田求磨, 田邊嘉也，他. 高齢者市 中肺炎の重症度分類と予後予測. 日老医誌 2007 ; 44(4) : 483-489.
5 ) Partridge JS, Harari D, Dhesi JK. Frailty in the older surgical patient: a review. Age Ageing $2012 ; 41(2): 142-147$.

6 ) Rockwood K, Mitnitski A. Frailty in relation to the accumulation of deficits. J Gerontol A Biol Sci Med Sci 2007 ; 62(7) : 722-727.

7 ) de Vries NM, Staal JB, van Ravensberg CD, et al. Outcome instruments to measure frailty : a systematic review. Ageing Res Rev $2011 ; 10(1)$ : 104-114.

8 ) Rockwood K, Song X, MacKnight C, et al. A global clinical measure of fitness and frailty in elderly people. CMAJ $2005 ; 173(5)$ : 489-495.

9 ) 寺本信嗣。誤嚥による肺炎を防ぐ・治す。日医雑 誌 $2006 ； 135(6) ： 1287-1290$.

10) Teramoto S, Fukuchi Y, Sasaki H, et al. High incidence of aspiration pneumonia in community- and hospital-acquired pneumonia in hospitalized patients : a multicenter, prospective study in Japan. J Am Geriatr Soc 2008 ; 56(3) : 577-579.

11）福山 一, 石田 直，橘 洋正，他. 在宅介護寝 たきり肺炎の臨床的検討。日呼吸会誌 $2010 ； 48$ (12) : 906-911.

12) Boyce JM, Potter-Bynoe G, Dziobek L, et al. Nosocomial pneumonia in Medicare patients. Hospital costs and reimbursement patterns under the prospective payment system. Arch Intern Med 1991; 151(6) : 1109-14.

13）吉澤明孝，石黒俊彦，吉澤孝之．在宅看取りの現 状と問題点. 臨牀と研究 $2013 ; 90(4) ： 473-$ 477.

14) Givens JL, Jones RN, Shaffer ML, et al. Survival and comfort after treatment of pneumonia in advanced dementia. Arch Intern Med 2010; 170(13) : 1102-1107.

15) Fried LP, Tangen CM, Walston J, et al. Frailty in older adults: evidence for a phenotype. J Gerontol A Biol Sci Med Sci 2001 ; 56(3) : M146 -156 .

16）坂本直治，杉原栄一郎，朴 宗晋，他. 高齢者市 中肺炎の死亡例に関する検討. 日老医誌 2010 ； $47: 47-51$.

17) Clegg A, Young J, Iliffe S, et al. Frailty in elderly people. Lancet $2013 ; 381(9868)$ : $752-762$.

18) Odden MC, Peralta CA, Haan MN, et al. Rethinking the association of high blood pressure with mortality in elderly adults : the impact of frailty. Arch Intern Med $2012 ; 172(15)$ : 11621168

19) Yau CK, Eng C, Cenzer IS, et al. Glycosylated 
hemoglobin and functional decline in community-dwelling nursing home-eligible eld- erly adults with diabetes mellitus. J Am Geriatr Soc 2012 ; 60(7) : 1215-1221.

\title{
Relationships Between Pneumonia and Frailty in Elderly Patients in Rural Area
}

\author{
Takuya SHIRAISHI*
}

\begin{abstract}
Background and Purpose : As the population in Japan is rapidly graying, elderly pneumonia patients are increasing. Even if elderly patients undergo the same treatments as younger patients, their outcomes would be all too often disappointing. This would make it difficult for doctors to judge whether they should continue to give medical treatment or not. So, we decided to examine relationships between frailty and outcomes of treatments of pneumonia in elderly patients in a rural area. Methods : Participants were elderly patients aged 75 years or older who were treated for pneumonia in our clinic between April 2014 and January 2015. Clinical course, disease severity classifications and frailty of the patients were investigated. Results : Seven patients (three men and four women; mean age 87.7 years) were analyzed. As frailty advances, some patients died in hospital or were discharged to more to an institutional care facility. Conclusion : Frailty may have been related to their bad results after pneumonia treatments. We may be able to predict their out-of-hospital health state by presence or absence of frailty.
\end{abstract}

*Uenomura Remote Place Clinic, Gunma, Japan 